\title{
Historical Eras and Abbreviations
}

Historical Eras Mentioned in Text:

Warring States Period 481-221 BCE

Tang Dynasty, 618-907 CE

Northern Song Dynasty, 960-1126

Southern Song Dynasty, 1127-1276

Ming Dynasty, 1368-1644

Qing Dynasty, 1644-1911

Republic, 1912-49

People's Republic of China, 1949-present

Abbreviations for Reign Titles of Qing Emperors used in text for Qing period dates, which are given in terms of the Chinese lunar calendar, followed by Gregorian calendar equivalents in parentheses: Ex., GX34.12.27 refers to the twenty-seventh day of the twelfth month of the thirty-fourth year of the Guangxu reign, that is, January 18, 1909 CE of the Gregorian Calendar. Because the Republic adopted the Gregorian calendar, dates from the Republican period are given in terms of the Gregorian calendar in the same Day-Month-Year format as the preceding example. If a Republican document gives the lunar calendar date or it is unclear as to which calendar is being used, the date is given in the same Year.Month.Day format as for Qing period dates. Republican dates in which the year was originally listed as "1st, 2nd, $3 \mathrm{rd}$... Year of the Republic" or according to the sixty-year Celestial Stem-Terrestrial Branch Cycle are given in terms of the equivalent Common Era (CE) year.

SZ: Shunzhi 1644-61

KX: Kangxi 1662-1722

YZ: Yongzheng 1723-35 
xvi / Historical Eras and Abbreviations

QL: Qianlong 1736-95 (This emperor continued to rule for three abdication years, 1796-9).

JQ: Jiaqing 1796-1820

DG: Daoguang 1821-50

XF: Xianfeng 1851-61

TZ: Tongzhi 1862-74

GX: Guangxu 1875-1908

XT: Xuantong 1909-12 
Shang you tiantang, xia you Su Hang. Above is Heaven, Below are Suzhou and Hangzhou.

-Popular maxim dating from the Southern Song dynasty.

"Within cities, it is as with dreams: everything imaginable can be dreamed, but even the most unexpected dream is a rebus that conceals a desire or, its reverse, a fear. Cities, like dreams, are made of desire and fears, even if the thread of their discourse is secret, their rules are absurd, their perspectives deceitful, and everything conceals something else."

"I have neither desires nor fears," the Khan declared, "and my dreams are composed either by my mind or by chance."

"Cities also believe they are the work of the mind or of chance, but neither the one nor the other suffices to hold up their walls. You take delight not in a city's seven or seventy wonders, but in the answer that it gives to a question of yours."

$$
\text { -Italo Calvino, Invisible Cities, } 1974
$$

To be modern is to find ourselves in an environment that promises us adventure, power, joy, growth, transformation of ourselves and the world - and, at the same time, that threatens to destroy everything that we have, everything we know, everything we are. Modern environments and experiences cut across all boundaries of geography and ethnicity, of class and nationality, of religion and ideology: in this sense, modernity can be said to unite all mankind. But it is a paradoxical unity, a unity of disunity: it pours us all into a maelstrom of perpetual disintegration and renewal, of struggle and contradiction, of ambiguity and anguish. To be modern is to be part of a universe in which, as Marx said, "all that is solid melts into air." 
